(C) Entomologica Fennica. 16 June 2006

\title{
The emergence of Halocladius variabilis (Staeger) (Diptera: Chironomidae) in the surroundings of the Tvärminne Biological Station in the northern Baltic Sea
}

\author{
Mauri Hirvenoja, Ernst Palmén† \& Elina Hirvenoja
}

Hirvenoja, M., Palmén, E. \& Hirvenoja, E. 2006: The emergence of Halocladius variabilis (Staeger) (Diptera: Chironomidae) in the surroundings of the Tvärminne Biological Station in the northern Baltic Sea. — Entomol. Fennica 17: 8789.

The emergence of the marine species Halocladius variabilis (Staeger) in the surroundings of the Tvärminne Biological Station (about $6 \% \mathrm{~S}$ ) in the northern Baltic Sea in 1952-1953 is outlined. Most individuals emerged in the submerged funnel traps used in the study from the last half of May to the end of June. The population density in the sites studied varied between 0 and 328 indiv. $/ \mathrm{m}^{2}$; wide areas had a population density of nearly $10 \mathrm{indiv} . / \mathrm{m}^{2}$. No emergence was found in the traps nearest to the buildings of the station, but the highest numbers of the emergence occurred in the most distant sites studied.

\section{Hirvenoja \& E. Hirvenoja, Sotilaskorventie 13, FI-01730 Vantaa, Finland}

Received 26 February 2004, accepted 8 February 2005

\section{Introduction}

In 1952 the late Prof. E. Palmén began to collect aquatic emerging insects with submerged funnel traps (Brundin 1949) in the surroundings of the Tvärminne Biological Station in the northern Baltic Sea. A brief description of sites 1-29 (1952) and 30-50 (1953) is included in a paper by Palmén (1962). Localities 60-69 and 70-78 studied later on are briefly described in a paper by Palmén \& Aho (1966). Because of his other duties, Palmén became totally estranged from these studies. This is why large parts of his materials, especially those concerning the occurrence of the fresh water species in the brackish water areas, have still today not been characterised. Some of his determined as well as undetermined materials preserved in alcohol are in the collections of the Finnish Museum of Natural History, Helsinki.

Palmén's notebook, which is also in the Finn- ish Museum of Natural History, Helsinki, includes the information given below about the marine chironomid species Halocladius variabilis (Staeger), collected in 1952 and 1953, under the name Cricotopus (Trichocladius) vitripennis $\mathrm{K}$.

The main distribution areas of $H$. variabilis are the eastern and western shores of the northern Atlantic Ocean, the Baltic Sea, the Mediterranean Sea and the Black Sea (Hirvenoja 1973). It is one of the few marine species in Finland and the only species of this genus in the Baltic Sea. It occurs northwards on the southern shore of the Gulf of Finland near the town of Narva, northern Estonia (Järvekülg 1979: Fig. 66, sub Trichocladius vitripennis Meigen). Its distribution outside the betamesohaline Tvärminne area in Finland is unknown. The material treated in the present paper originates from the shallow littoral areas, but Palmén and Lindeberg (1959, under the names Clunio marinus Haliday and Trichocladius vitri- 


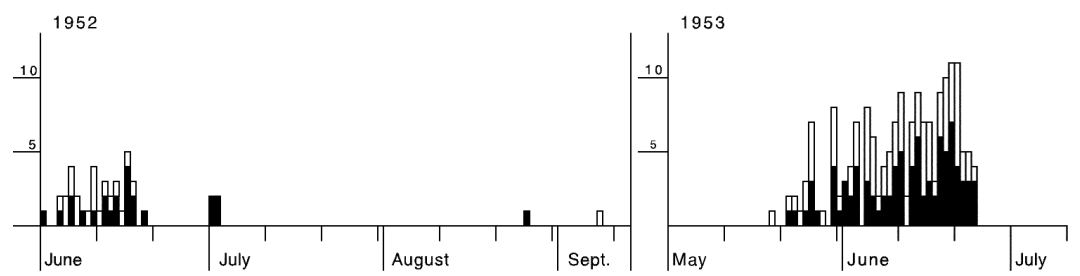

Fig.1. The sum of the daily emergence of Halocladius variabilis (Staeger) in the Tvärminne sea area in 1952 and 1953 based on 29 or 30 submerged $0.25 \mathrm{~m}^{2}$ funnel traps, respectively. Dark columns, females; white columns, males.

pennis Meigen) reported that pupal exuviae of $H$. variabilis occur very regularly in the same surface samples, where Clunio balticus Heimbach was found in areas more than $10 \mathrm{~m}$ deep. In contrast to $H$. variabilis, the latter species is very rare in shallower areas.

$H$. variabilis has not been found in freshwater habitats, but Santhakumaran et al. (1984) report, that the larvae were unaffected when placed in distilled water and could withstand salinities as high as $70.5 \%$ when transferred directly from distilled water and $97.0 \%$ after acclimation. According to those authors the larvae were present in Trondheimsfjorden, Norway, among a variety of fouling communities ranging from a thin film of algae and silt to extremely heavy settlements of coelenterates, serpulids, barnacles, bivalves, bryozoans, ascidians, or algae together with a thick layer of silt and faeces of polychaetes, ascidians, and wood-borers.

\section{Population density at Tvärminne based on the emergence}

There were a total of 29 funnel traps each $0.25 \mathrm{~m}^{2}$ in area, used in 1952 and 30 traps in 1953 at the sites near the Biological Station. They are numbered in the map given by Palmen (1962). The population density of $H$. variabilis was low in 1952 with a maximum of 5 indiv. $/ 0.25 \mathrm{~m}^{2}(=20$ indiv. $\left./ \mathrm{m}^{2}\right)$. At the 15 sites (= traps) where emergence was observed, the mean population density can be converted to 10.4 indiv. $/ \mathrm{m}^{2}$.

In traps 1-6, 8-12 and 27-28 no individuals emerged in 1952. Sites 1-6 in Krogarviken Bay (depths 1-7 m) that has abundantly vascular plants were nearest to the Station buildings. The other sites 8-12 and 27-28 without emergence of
$H$. variabilis were in the surroundings of the nearest islands Vikaskär and Jovskär opposite to Krogarviken Bay. At that time, the Biological Station had no wastewater purifying plant. This situation may have had some influence on the aquatic biota.

Unfortunately, no information is available for the water chemistry in the Tvärminne area 19521953. Traps were also set in summer 1953 in some of the sites studied in $1952(1-2,12-13 a-b$, 27-29), but sites 30-51 were new. No subsequent emergence of $H$. variabilis was observed in 1953 in Krogarviken Bay or in traps 34-37 near the shore of Jovskär island.

The highest population density in 1953 was at sites 45-47, at the eastern tip of Longholmen about $700-800 \mathrm{~m}$ from the buildings of the Biological Station. At site 45 (depth $6 \mathrm{~m}$ ) the density can be converted from the emergence to 328 indiv. $/ \mathrm{m}^{2}$. The nearest traps, 46 and 47 (depths 12 and $13 \mathrm{~m}$ ), produced smaller catches. The vertical distribution of the larvae is not known in the Baltic Sea. Most of the sites studied in 1953 were at a greater distance from the Biological Station than those in 1952, and the mean catch in 1953 was higher, being 23.6 indiv. $/ \mathrm{m}^{2}$.

\section{Phenology of $\boldsymbol{H}$. variabilis in the Tvärminne sea area}

As mentioned above, the population density of $H$. variabilis was very low in most of the sites studied. Therefore, the daily catches of all traps are combined into the histograms in Fig. 1, where in both years the total catch originated from 29 or 30 (1953) traps (each $0.25 \mathrm{~m}^{2}$ ), i.e. the daily columns are the sums of catches from total areas of 7.25 or $7.50 \mathrm{~m}^{2}$. These areas also include the traps 
(sites) where the emergence of $H$. variabilis was not observed.

The occurrence of two or more emergence periods during a season is a quite common phenomenon in the life cycle of the littoral chironomids. Fig. 1 shows that the population of $H$. variabilis in the Tvärminne sea area is univoltine. It emerges from the last half of May to the end of June, perhaps when the bottom water temperature is above $+4^{\circ} \mathrm{C}$ and the surface water temperature exceeds about $+8^{\circ} \mathrm{C}$ (see Fig. 13 in Palmén \& Aho 1966: the development of the temperature in 1960). There happened also occasional emergences in the Tvärminne population during the other summer months.

Acknowledgements. Thanks are due to Mr. Donald Smart for revision of the language.

\section{References}

Brundin, L. 1949: Chironomiden und andere Bodentiere der Südschwedischen Urgebirgseen. Ein Beitrag zur
Kenntnis der Bodenfaunistischen Characterzüge schwedischer oligotropher Seen. [With English summary]. - Inst. Freshw. Res. Drottningholm, Rep. 30: 1-914.

Hirvenoja, M. 1973: Revision der Gattung Cricotopus van der Wulp und ihrer Verwandten (Diptera, Chironomidae). - Ann. Zool. Fennici 10: 1-363.

Järvekülg, A. 1979: The bottom fauna of eastern part of the Baltic Sea. [In Russian]. - 382 pp. Valgus, Tallinn, Estonia.

Palmén, E. 1962: Studies on the ecology and phenology of the Chironomids (Dipt.) of the Northern Baltic. 1. Allochironomus crassiforceps K. - Ann. Entomol. Fennici 28: 137-168.

Palmén, E. \& Aho, L. 1966: Studies on the ecology and phenology of the Chironomidae (Dipt.) of the Northern Baltic. 2. Camptochironomus Kieff. and Chironomus Meig. - Ann. Zool. Fennici 3: 217-244.

Palmén, E. \& Lindeberg, B. 1959: The marine midge, Clunio marinus Hal. (Dipt., Chironomidae), found in Brackish water in the northern Baltic. - Int. Rev. Ges. Hydrobiologie 44: 383-394.

Santhakumaran, L.N., Sneli, J.-A.. \& Sundnes, G. 1984: The larvae of (Halocladius (Halocladius) variabilis (Diptera: Chironomidae) from the fouling assemblages on wooden test panels submerged in Trondheimsfjorden. - Sarsia 69: 155-158. 